\title{
THE PRICE OF EXPERIENCE: THE CONSTITUTION AFTER SEPTEMBER 11, 2001
}

\author{
J. Gregory Sidak*
}

What is the price of experience? Do men buy it for a song?

Or wisdom for a dance in the street? No, it is bought with the price

Of all a man hath, his house, his wife, his children.

Wisdom is sold in the desolate market where none come to buy,

And in the wither'd field where the farmer plows for bread in vain.

From William Blake's The Price of Experience (1797)

\section{INTRODUCTION}

For a half-century, Youngstown Sheet \& Tube Co. v. Sawyer has been the starting point for judicial reasoning and academic conjuring about the separation of powers between Congress and the President and, more specifically, presidential prerogative asserted in the name of national security. ${ }^{1}$ The collective experience acquired on September 11, 2001, has supplanted Youngstown. The memorable phrases in Youngstown still inspire, but they no longer reliably say what the law is, if one uses Oliver Wendell Holmes's formulation that "[t]he prophecies of what the courts will do in fact, and nothing more pretentious, are what I mean by the law." ${ }^{2}$ The Constitution did not change on September 11th. ${ }^{3}$ The innocence of the current generation of

* F. K. Weyerhaeuser Fellow in Law and Economics Emeritus, American Enterprise Institute for Public Policy Research. I thank Michael Stokes Paulsen, Melinda Ledden Sidak, and Leigh Tripoli for their generous comments and Louisa Fuller for valuable research assistance. I wrote this essay between December 2001 and January 2002 and, in the interest of keeping it a snapshot in time, have made minimal changes to account for subsequent events. (C2002 by J. Gregory Sidak.

1. 343 U.S. 579 (1952).

2. Oliver Wendell Holmes, The Path of the Law, 10 Harv. L. Rev. 457, 461 (1897).

3. Consequently, I would not say that September 11th was a "constitutional moment" within Bruce Ackerman's framework of implicit amendment of the Constitution. See Bruce Ackerman, 1 We the People: Foundations (Belknap Press of Harvard U. Press, 1991). 
Americans changed. They read the same words now with a different experience. As a consequence, Youngstown will recede as a reliable predictor of the boundaries of presidential prerogative in matters of national security and, to a lesser extent, as the touchstone of separation-of-powers analysis.

\section{INNOCENCE AND EXPERIENCE}

Innocence is a priori reasoning untested by empiricism, which is to say experience. ${ }^{4} \mathrm{I}$ approach innocence and experience from the evolutionary perspective of Karl Popper, who described as "the principle of empiricism" the following proposition: "Only "experience' can help us to make up our minds about the truth or falsity of factual statements." Put another way, knowledge of the truth or falsity of an a priori proposition is held captive by the limits of one's empirical experience.

September 11th was, to use the language of statistics, an outof-sample event for Americans not old enough to remember Pearl Harbor. Americans were incredulous because, for most of them, nothing in their own experience would cause them to believe that such attacks were possible. The same lack of experience presumably caused the passengers on the two airlines that struck the World Trade Center towers never to consider that their hijackers intended not to exact ransom but to use the airplanes as bombs. Even the current military appeared to have suffered from a lack of experience, despite its unquestioned institutional knowledge from prior wars. Only fourteen fighters were patrolling the entire United States at the time of the attacks. ${ }^{6}$ The Air Force Reserve jets that scrambled to Washington flew from Hampton, Virginia, and Falmouth, Massachusetts - not nearby Andrews Air Force Base. $^{7}$ When they arrived and were ordered by the Secret Ser-

4. "Experience," wrote Immanuel Kant, "is without doubt the first product that our understanding brings forth as it works on the raw material of sensible sensations." Immanuel Kant, Critique of Pure Reason 127 (Paul Guyer and Allen W. Wood, eds., Cambridge U. Press, 1998) (1781). He argued that "universal cognitions, which at the same time have the character of inner necessity, must be clear and certain for themselves, independently of experience; hence one calls them a priori cognitions: whereas that which is merely borrowed from experience is, as it is put, cognized only a posteriori, or empirically." Id.

5. Karl R. Popper, Objective Knowledge: An Evolutionary Approach 12 (Oxford at the Clarandon Press, 1972). For an empirical view of constitutional interpretation that builds on Popper's theory of objective knowledge, and Friedrich Hayek's related theory of the evolutionary nature of markets, see J. Gregory Sidak, Mr. Justice Nemo's Social Statics, 79 Tex. L. Rev. 737 (2001).

6. Matthew L. Wald and Kevin Sack, A Nation Challenged: The Tapes; "We Have Some Planes,"' Hijacker Said on Sept. 11, N.Y. Times A1 (Oct. 16, 2001).

7. Id. 
vice to "protect the White House at all costs," it was too late. ${ }^{8}$ The Pentagon was already in flames. It was not fighter planes that succeeded in defending the White House from the fourth team of terrorists, but rather a subset of We the People on United Airlines Flight 93. Like modern day Minutemen, they scuttled their hijacked airliner in Pennsylvania after learning by cell phone that more lives than their own would be lost if they failed to resist.

There is no reason to think that jurists and legal scholars are different from other Americans in the way that innocence and experience affect how they analyze a problem. Justice Holmes famously wrote: "[a] page of history is worth a volume of logic." And it is said that the hardness of some of Holmes's judicial opinions may have reflected his experience of having fought in the Civil War, during which time he was wounded on three occasions. ${ }^{10}$ For two generations or more, American legal scholars had little cause, even during the height of the Cold War, to consider constitutional matters that concerned the immediate defense and survival of the United States. There was some small chance that cities and strategic targets in America would be incinerated in a nuclear puff, as was feared during the Cuban missile crisis, but there was no serious fear of a conventional attack causing massive civilian casualties.

By all accounts, the attacks of September 11th produced for millions of citizens an intensely personal process of revelation and reflection. I relate some of my own revelations and reflections, not because they are special in any way, but because they are mine, and thus they permit me to speak without speculation. Their familiarity helps me to express how constitutional interpretation at any moment in American history may reflect the tension between abstract reasoning and the shared experiences of events that have changed the lives of the nation's citizens.

From my office in downtown Washington, I watched the huge plume of smoke rising from the Pentagon on the morning of September 11th. The experience gave me a new insight on facts that I already knew. My uncle, Bud, was a farm boy from Nebraska who became an aircraft mechanic in the Army Air Corps and was stationed at Hickam Field on Oahu. He was gravely

\footnotetext{
8. Id.

9. N.Y. Trust Co. v. Eisner, 256 U.S. 345, 349 (1921).

10. See, e.g., Richard A. Posner, ed., The Essential Holmes: Selections from the Letters, Speeches, Judicial Opinions, and Other Writings of Oliver Wendell Holmes, Jr. ix-x (U. of Chicago Press, 1992).
} 
wounded by shrapnel from a Japanese bomb on the morning of December 7, 1941, and for the remainder of his life suffered in body and mind, a ward of the Veterans Administration. My father, unable to go to war because of polio, worked instead at a defense factory in San Diego that turned out aircraft parts. His older sister Annie stayed to help run the family farm while two younger sisters, Julia and Wilma, left Nebraska to work at the same factory in San Diego. Julia married a Marine paratrooper who later fought on Iwo Jima and Okinawa. Wilma became a war widow, her hometown sweetheart killed during a bombing mission over Italy just before D Day. The youngest boy in the family, Don, also left the farm for San Diego and the same aircraft plant. On his eighteenth birthday, he enlisted to become a naval aviator. At twenty, he flew torpedo bombers from aircraft carriers. During the Cold War, Major Sidak of the Strategic Air Command piloted a B-47 armed with thermonuclear bombs, his designated target the Kremlin. He and his brothers never returned to work the farm.

As a child, I knew these family stories. And though my childhood was spent in San Diego, a city still dominated in the 1960s by the Navy and the defense industry, as a whole my understanding of the consequences of war and the price of peace had the vicarious translucence of a John Wayne movie. What I thought I understood, I knew not from experience, but from the innocent abstraction of someone who had been spared the consequences of war through the sacrifices of others. Even when I had the tangible experience as a nine-year-old of climbing into the cockpit of Uncle Don's B-47, I did not comprehend that, if the order ever came for him to use the bomber for its intended purpose, the chances of our seeing one another again on this earth would be nonexistent. Several decades passed before I began to comprehend how much I had not understood.

In 1996, after my father was gone and I had sons of my own, I found among his possessions the front-page of the Cedar County News from December 1941. Its banner headline reported Bud among the casualties at Pearl Harbor. My grandfather was quoted saying that he would gladly fight the Japanese himself if the Army would take him. To hold the yellowed newspaper in my hands was to hear the words of anger and grief passing from my grandfather's lips 55 years earlier, to comprehend, as if transported in a time machine, what Pearl Harbor meant for one father's love for his son, and what it would mean for the family into which I had not yet been born. Like an epiphany in a James 
Joyce novel, the whatness of Pearl Harbor at that moment leapt to me "from the vestment of its appearance." II I understood how my own father and his siblings had dedicated themselves to obliterating the evil that had spilled their brother's blood one Sunday morning in 1941. Whether they took up arms or helped to make them, farmers became warriors, their fidelity measured by how these brothers and sisters led their lives and, in time, by how they strove to impart to their children a wisdom "bought with the price of all a man hath."

\section{THE EBB OF YOUNGSTOWN}

Measured by the standard of wisdom bought with experience, the abstract erudition of Supreme Court decisions impresses me less than it once did. Its purveyors are too susceptible to getting carried away with their wares, producing euphonic sophistry that is devoid of empirical perspective. A former law review president clerking on the Supreme Court probably could craft a respectable opinion that reasoned that American soldiers scaled the cliffs of Normandy to protect the separation of powers, "the better to secure liberty." 12 But a clever turn of phrase does not make an abstract proposition true.

For the thousands murdered at the World Trade Center and the Pentagon, the orations in Youngstown about the separation of powers rang hollow: These victims lost not only liberty, but life. The carnage of September 11th will transform a new generation of Americans as much as Pearl Harbor transformed my Uncle Bud and his family back home. With the collective experience of September 11th, we can now see, after years of selfindulgence masquerading as virtue, that liberty and security are more than abstractions to be manipulated in elegantly written Supreme Court opinions. A world of danger cannot be dismissed with pretty words. Youngstown has an unstated premise that the threat to liberty from foreign aggression is less than the threat to liberty when the President claims expansive powers to defend the nation from such aggression. September 11th was an awakening, an epiphany, to the empirical fact-not the abstract notion-that America had underestimated the danger of deadly

11. James Joyce, Stephen Hero 213 (Theodore Spencer, ed., Vail-Ballow Press, 1944). Though a nonbeliever, Joyce obviously borrowed his literary concept from the Feast of the Epiphany.

12. Youngstown, 343 U.S. at 635 (Jackson, J., concurring). 
aggression on its soil. Wrenched from contentment, we can now see that there is less to Youngstown than meets the eye.

\section{A. SOME GROUND RULES FOR A SKEPTICAL READING}

I take the editor's cue that the purpose of this symposium issue of Constitutional Commentary is to assess the relevance of Youngstown to American constitutional law a half-century later. The majority opinion in Youngstown does not age well. Other passages in the concurrences, by Justices Jackson and Frankfurter in particular, are more enduring as essays about American governance. The United States, however, is not a hagiocracy, and famous Supreme Court decisions, Youngstown included, deserve skepticism rather than genuflection. The opinions of the Supreme Court are not the only sources of wisdom about reading the Constitution. The collective experience of witnessing thousands of American civilians slaughtered on American soil by foreign terrorists on September 11, 2001, is far more important to reading the Constitution today than is a case about the backlash to the legally clumsy attempt, by a famously unpopular President, to invoke national security as the justification for seizing steel mills during a labor dispute in 1952, an election year in which control of the White House subsequently shifted from one party to the other.

I approach my skeptical assessment of Youngstown with several ground rules in mind. First, for the purpose of writing this essay, and partly because of the tight schedule for this symposium issue, I have intentionally read the opinion only once. The last time I read Youngstown carefully was more than a decade ago in connection with the research for a series of articles that I wrote on separation-of-powers topics. ${ }^{13}$

Second, I have undertaken what might be called a "Scalian" reading of Youngstown. If Youngstown is really such a landmark, then its importance should be readily discernible from the four corners of the opinion, without reference to the voluminous secondary literature that the case has generated or the subsequent discussions of the case by the Supreme Court or other courts. More specifically, the importance of the decision should be clear

13. See J. Gregory Sidak, War, Liberty, and Enemy Aliens, 67 N.Y.U. L. Rev. 1402 (1992); J. Gregory Sidak, To Declare War, 41 Duke L.J. 27 (1991); J. Gregory Sidak and Thomas A. Smith, Four Faces of the Item Veto: A Reply to Tribe and Kurland, 84 Nw. U. L. Rev. 437 (1990); J. Gregory Sidak, The President's Power of the Purse, 1989 Duke L.J. 1162 (1989); J. Gregory Sidak, The Recommendation Clause, 77 Geo. L.J. 2079 (1989). 
from a cold reading of the actual words of the majority opinion, which counts for only a small fraction of the ink spilled by the Justices. I have not attempted to get into the heads of the Justices to explore the Zeitgeist of Youngstown. Judicial intent in 1952 is irrelevant. My analysis is very practically minded: What immediate questions arise when a skeptical lawyer reads Youngstown in 2002? After September 11, 2001, is Youngstown still useful in understanding the tradeoff between individual freedom and national security?

\section{B. JUSTICE BLACK'S OPINION FOR THE COURT}

Justice Hugo Black wrote the opinion for the 6-3 majority. It addressed two legal questions concerning President Truman's seizure of steel mills during a strike in 1952, while the Korean War was still in process:

First. Should final determination of the constitutional validity of the President's order be made in this case which has proceeded no further than the preliminary injunction stage? Second. If so, is the seizure order within the constitutional power of the President? ${ }^{14}$

Justice Black's opinion has the virtue of being brief, but its answers to both questions are unpersuasive. I consider first the ripeness question, which has a remedies question embedded within it.

\section{The Takings Question}

Justice Black found the takings claim ripe, but his reasoning is vague and rests heavily on his agreement with the district court, whose reasoning in turn he never explained, even in the factual introduction to the opinion. ${ }^{15}$ So, unless we go read the district court opinion (issued only two weeks before the Supreme Court heard oral argument ${ }^{16}$ ), we cannot really say why the case was ripe. But referring to the lower decision would violate my Scalian ground rule that the reasoning of the majority opinion of a landmark case should be clear from its own plain wording.

Next, Justice Black found that the claims of the steel mill owners deserved an injunctive remedy-overriding an order by the

14. Youngstown, 343 U.S. at 584.

15. Id.

16. Id. at 584. The district court issued its injunction on April 30, 1952. The U.S. Court of Appeals for the D.C. Circuit stayed the injunction the same day. The Supreme Court granted certiorari on May 3 and heard argument on May $12 \& 13,1952$. Id. 
President of the United States-because "seizure and governmental operation of these going businesses were bound to result in many present and future damages of such nature as to be difficult, if not incapable, of measurement." ${ }^{17}$ Justice Black reached this conclusion before explaining the Court's holding with respect to the separation-of-powers question posed by the case. So the rationale for enjoining the taking could not have been that it was $u l$ tra vires. The proposition that the seizure of an ordinary business like a steel mill is not susceptible of being compensated in monetary terms is as breathtaking as it is silly. One wonders how the sale or hypothecation of a steel mill could ever take place if a routine discounted cash flow calculation were really so daunting as Justice Black would make it seem.

Since the passage of the Telecommunications Act of 1996, questions of the ripeness of a taking and the measurement of just compensation have arisen in complex litigation in which incumbent local exchange carriers (ILECs) have asserted that the regulated rates that they must offer to competitive local exchange carriers (CLECs) for "unbundled" access to the incumbent telecommunications networks are confiscatory. ${ }^{18}$ The ILECs would love to have courts extend to their claims the same judicial solicitude toward takings claims exhibited in Youngstown. But, of course, that solicitude does not exist today. ${ }^{19}$ Viewed a halfcentury later, Youngstown is an aberration as a takings case in the sense that the private property owner succeeded in enjoining the confiscation rather than having to settle for a damage remedy that took for granted the lawfulness of the confiscation. It is improbable that any attorney today representing a party in takings litigation would build his case around Youngstown. That bit of common sense is consistent with the view that the Court in Youngstown blew past the takings issue, making unreliable law, to reach the separation-of-powers question.

One might argue, to the contrary, that if there is no presidential power to take private property absent congressional authorization, then the effect of denying injunctive relief is to compel Congress to appropriate funds to compensate private parties for a presidential invasion of Article I powers. I disagree for two reasons. First, the immediate effect of denying an injunction

17. Id. at 585 .

18. Verizon Communications Inc. v. FCC, 122 S. Ct. 1664, 1679-81 (2002) (dismissing ILECs takings arguments).

19. See, e.g., Pennell v. City of San Jose, 485 U.S. 1 (1988) (holding taking claim not ripe). 
against the alleged presidential taking is, rather, to force the courts to adjudicate whether a taking has actually occurred. If none has, then the question of whether damages or an injunction is the proper remedy disappears. Second, Article II repeatedly states that the President "shall have Power" to discharge the executive duties that the Constitution assigns him. ${ }^{20}$ If it means anything in this context, "Power" must encompass the lawful ability to obligate the Treasury in limited circumstances required for the President's discharge of those textually assigned duties. ${ }^{21}$ The fact that section 2 of Article II does not state that the President "shall have Power" to command the army and navywhereas he "shall have Power to grant Reprieves and Pardons," for example ${ }^{22}$-does not imply that the President shall have no "Power" to "be Commander in Chief." To "be" without having the "Power" to $d o$ would be vacuous.

Apart from being completely unbelievable on its face as an interpretation of the Takings Clause, the Court's conclusion that the seizure of the steel mills had no monetary remedy is contradicted by its own takings jurisprudence from the World War II era. In Kimball Laundry Co. v. United States, ${ }^{23}$ the Court in 1949, in an opinion written by Justice Frankfurter, recognized a right to compensation for the temporary taking of a private laundry by the military during World War II. Curiously, none of the opinions in Youngstown discusses or even cites Kimball Laundry. The temporary seizure of a steel mill during wartime to ensure a steady supply of weapons seems a great deal more defensible than the temporary seizure during wartime of a laundry to ensure a steady supply of clean towels. Perhaps the latter was authorized by statute while former was not. But that distinction should have been irrelevant at this stage of Justice Black's opinion, as he did not address the separation-of-powers question (and hence the possibility of ultra vires action by the President) until after he had found the seizure of the steel mills to present a ripe takings claim.

Moreover, the asserted difficulty of measuring the "present and future damages" from the seizure of steel mills was a canard. The same difficulty routinely arises in any civil litigation, yet equitable relief is the exception rather than the rule. Takings cases raise no unique and insuperable problem of measurement or

20. U.S. Const., Art. II, $\S 2$.

21. See Sidak, 1989 Duke L.J. at 1185 (cited in note 13).

22. U.S. Const., Art. II, \& 2, cl. 1

23. 338 U.S. 1 (1949). 
causation. In Kimball Laundry, Justice Frankfurter only three years earlier displayed great agility in addressing how compensation should be calculated for the federal government's temporary taking of a business during wartime. Indeed, Kimball Laundry arguably contains the most penetrating economic reasoning of any of the Court's takings decisions of the twentieth century, because it established the principle that the correct measure of just compensation is the property owner's opportunity cost. ${ }^{24}$ In addition, many earlier decisions of the Supreme Court concerning allegations of confiscatory ratemaking for utilities, such as Justice Douglas's 1944 opinion for the Court in Hope Natural Gas, demonstrate that the Court is able and willing to evaluate detailed methods of business valuation. ${ }^{25}$ Why the lost profits of a steel mill are any harder to measure than the fair return on the invested capital of a railroad or a telephone company or an electric utility is not explained anywhere in Justice Black's opinion in Youngstown.

\section{The Separation-of-Powers Question}

Justice Black took a mere eight paragraphs to answer the separation-of-powers question. His first sentence states: "The

24. Where income-generating business facilities are appropriated on an ongoing basis for government use, or where the government grants third parties mandatory rights of access to and use of that property, compensation for that involuntary exchange is "just" if it equals the price to which a willing buyer and a willing seller would agree. In Kimball Laundry, Justice Frankfurter wrote for the Court:

The value compensable under the Fifth Amendment ... is only that value which is capable of transfer from owner to owner and thus of exchange for some equivalent. Its measure is the amount of that equivalent. But since a transfer brought about by eminent domain is not a voluntary exchange, this amount can be determined only by a guess, as well informed as possible, as to what the equivalent would probably have been had a voluntary exchange taken place.

338 U.S. 5-6; accord, Olson v. United States, 292 U.S. 246, 255 (1934); United States v. Reynolds, 397 U.S. 14, 16 (1970). Subsequent scholarship has further explained the economic reasoning behind this insight that just compensation should replicate the outcome of voluntary exchange. See J. Gregory Sidak and Daniel F. Spulber, Deregulatory Takings and the Regulatory Contract: The Competitive Transformation of Network Industries in the United States 273-81 (Cambridge U. Press, 1997); Richard A. Epstein, Takings: Private Property and the Power of Eminent Domain 182 (Harvard U. Press, 1985). The voluntaryexchange standard corresponds to the concept of opportunity cost, which Professor Armen Alchian classically defined as follows: "the cost of an event is the highest-valued opportunity necessarily forsaken." Armen A. Alchian, Cost, in David L. Sills, ed., 3 International Encyclopedia of the Social Sciences 404 (Macmillan Co. \& The Free Press, 1968).

25. Fed. Power Comm'n v. Hope Natural Gas Co., 320 U.S. 591 (1944). The earlier decisions are numerous. See, e.g., Fed. Power Comm'n v. Natural Gas Pipeline Co. of Am., 315 U.S. 575, 585 (1942); Missouri ex rel. S.W. Bell Tel. Co. v. Pub. Serv. Comm'n, 262 U.S. 276 (1923); Smyth v. Ames, 169 U.S. 466 (1898); Covington \& Lexington Turnpike Rd. Co. v. Sandford, 164 U.S. 578 (1896); Monongahela Navigation Co. v. United States, 148 U.S. 312 (1893). 
President's power, if any, to issue the [steel seizure] order must stem either from an act of Congress or from the Constitution itself." ${ }^{26}$ Justice Black found neither form of authorization to be present. One can give this sentence a narrow reading: President Truman's power to seize steel mills, during a labor dispute, on the grounds of national security could not be reconciled with any statutory or constitutional authorization in light of circumstances in early 1952 . Perhaps different circumstances would produce a different result.

Alternatively, one can give the sentence a broader reading: A President's power on any subject must be authorized by an act of Congress or the Constitution itself. ${ }^{27}$ Put differently, with respect to the President's powers, everything that is not allowed is forbidden. Obviously, the broader reading is unnecessary to decide the case. But is not this grander reading the proposition that Youngstown is generally thought to represent? The grander proposition is what makes the concurring opinions of Justices Frankfurter and Jackson so quotable. If that were not true, the decision would not be so widely cited and commented upon, and there would be no reason to reflect upon the fact that fifty years have passed since the decision's issuance by the Supreme Court. ${ }^{28}$ So, for example, Professor Laurence Tribe states in his treatise that Youngstown "rebuffs any contention that the President is invested with unbridled discretion to act in the domestic arena, even in furtherance of military policy during wartime and even in matters affecting U.S. troops deployed in hostilities abroad[.] $]^{, 29}$

Justice Black characterized Youngstown as a labor case. Discussing the Taft-Hartley Act, ${ }^{30}$ he said that seizures of plants were not authorized by any legislation because "Congress had

26. Youngstown, 343 U.S. at 585. Later, Justice Black similarly said: "It is clear that if the President had authority to issue the order he did, it must be found in some provisions of the Constitution. And it is not claimed that express constitutional language grants this power to the President." Id. at 587.

27. At a textual level, this reading of Justice Black overlooks the question of whether, in the absence of enabling legislation, an obligation under a preexisting treaty would authorize the President to take actions, like President Truman's, that are not explicitly authorized by the Constitution.

28. Consider, for example, how Professor Laurence Tribe quotes Youngstown in his influential treatise. See Laurence H. Tribe, 1 American Constitutional Law (Foundation Press, 3d ed., 2000). He quotes the concurrences of Justice Douglas, Frankfurter, or Jackson more than Justice Black's majority opinion. See, e.g., id. at 151, 204 nn.6, 7, 633 n.1, 635 n.11, 637 n.1, 650 n. 34,669 nn. $73,75,671-72,785$.

29. Id. at 671

30. Labor Management Relations Act, 1947, 61 Stat. 136 
refused to adopt that method of settling labor disputes." ${ }^{31}$ Plant seizures "would interfere with the process of collective bargaining." 32 In other words, Justice Black characterized the objective of President Truman's actions to be to resolve a labor dispute, rather than to ensure the steady supply of a necessary input to prosecute a war. Justice Black rejected the proposition that the President's powers as Commander-in-Chief supplied the necessary authorization to seize the steel mills: "Even though 'theater of war' be an expanding concept, we cannot with faithfulness to our constitutional system hold that the Commander in Chief of the Armed Forces has the ultimate power as such to take possession of private property in order to keep labor disputes from stopping production." ${ }^{33}$ Justice Black brushed aside the cases cited by the government without even mentioning their names, let alone any attempt to distinguish them. ${ }^{34}$

Here it would appear that either Justice Black or President Truman was prevaricating. President Truman's executive order contained a long list of "whereas" clauses providing his justifications for seizing the steel mills, the most significant one being the following:

WHEREAS the weapons and other materials needed by our armed forces and by those joined with us in the defense of the free world are produced to a great extent in this country, and steel is an indispensable component of substantially all of such weapons and materials; ${ }^{35}$

Justice Black did not characterize the presidential objective in this way at all. He truncated the war objective from his characterization that President Truman's seizure of the steel mills was intended "to keep labor disputes from stopping production." President Truman saw the defense of the free world, while Justice Black, his sights a bit lower, saw a labor dispute. The stopping of production was relevant, according to President Truman, because it threatened the supply of weapons and materials for fighting the Korean War. Either President Truman was exagger-

31. Youngstown, 343 U.S. at 586.

32. Id. See also id. at 588 (Congress, but not the President, "can make laws regulating the relationships between employers and employees, prescribing rules designed to settle labor disputes, and fixing wages and working conditions in certain fields of our economy.").

33. Id. at 587.

34. Id. ("Such cases need not concern us here.").

35. Id. at 590 (quoting executive order of Apr. 8, 1952) (emphasis added).

36. Id. at 587 . 
ating the causal linkage between the steel strike and the prosecution of the war, or Justice Black was being disingenuous in severing the last and most critical link in President Truman's chain of argumentation. If Justice Black incorrectly characterized President Truman as meddling in a labor dispute that was covered by the Taft-Hartley Act, then it would be easy for the Court to knock down the straw man that the President's seizure of the steel mills was not implicitly authorized by Article II of the Constitution. On the other hand, if President Truman was using the Korean War as an excuse for siding with labor during a strike (it was obviously the steel mill owners, not the union, that challenged the seizure as a taking), then Justice Black was correct to expose the ruse.

The opinion then shifts gears. Next, Justice Black addressed the President's role in the making of laws. This passage is often cited to support the view that the President is less equal than Congress in the tripartite scheme of things:

In the framework of our Constitution, the President's power to see that the laws are faithfully executed refutes the idea that he is to be a lawmaker. The Constitution limits his functions in the lawmaking process to the recommending of laws he thinks wise and the vetoing of laws he thinks bad. ${ }^{39}$

This passage is notable for three reasons. First, it treats the President as a kind of cipher and his legislative powers as insubstantial. To the contrary, those legislative powers are substantial, precisely because synergies exist between the President's execution of law and his ascertainment of what new laws are needed and what old laws should be reformed or repealed. ${ }^{38}$ Second, the passage completely ignores the legislative function inherent in the President's duty under Article II to report to Congress annually on the State of the Union. ${ }^{39}$ Third, the passage ignores that the veto power itself resides in Article I, notwithstanding the Constitution's language that "All legislative Powers herein granted shall be vested in a Congress of the United States[.] ${ }^{, 40}$ If the specific grant of legislative powers to the President through the Veto Clauses did not survive this general grant of ostensibly

37. Id.

38. See Sidak, 77 Geo. L.J. at 2085-89 (cited in note 13).

39. See Vasan Kesavan and J. Gregory Sidak, The Legislator-in-Chief, 44 W. \& Mary L. Rev. 1 (2002).

40. U.S. Const., Art. I, $\S 1$ (emphasis added). The legislative powers inherent in the President's veto, id. $\$ 7$, cls. 2,3 , are explored in Sidak and Smith, 84 Nw. U. L. Rev. (cited in note 13). 
"All legislative Powers" to Congress, then it would have been nugatory for the Framers to give the President the veto power. Plainly, this is an example of constitutional text being internally inconsistent.

Justice Black recited that Congress had the exclusive power to enact legislation "to settle labor disputes" and "to make laws necessary and proper to carry out the powers vested by the Constitution" in all branches of the federal government. ${ }^{41}$ Then he delivered the most memorable line in the majority opinion: "The Founders of this Nation entrusted the law making power to the Congress alone in both good and bad times." ${ }^{\prime 2}$ This line is wonderful rhetoric-allusive of "for richer for poorer, in sickness and in health." ${ }^{43}$ But as a legal proposition it requires qualification for at least the three reasons listed above.

More fundamentally, this sentence returns us to the question of characterization. Was President Truman's seizure of the steel mills a legislative act, or was it a military act taken pursuant to his powers as Commander-in-Chief, "in the defense of the free world" in America's first open conflict of World War III? Justice Black's opinion for the Court so thoroughly denigrates the latter possibility that it runs the risk of overstating the case about the boundaries of presidential power in matters that genuinely do threaten national security, let alone matters that jeopardize the security of the entire free world. Read in this way, Youngstown is a power grab by the Court and Congress. It is reminiscent of the two notorious power grabs by Congress a generation later during the twilight of the Nixon presidency, when the United States was losing ground in the Cold War: the War Powers Resolution ${ }^{44}$ and the Congressional Budget and Impoundment Control Act of $1974 .{ }^{45}$ Shortly before his resignation, when Vietnam and Watergate had reduced President Nixon to the most disliked chief executive since President Truman, Congress enacted these two statutes by override of presidential vetoes and, in so doing, redefined by statute-illegitimately, in my view - the separation of powers on the consequential matters of war and spending. ${ }^{46}$ Perhaps Youngstown was the Court's way

\footnotetext{
41. Youngstown, 343 U.S. at 588-89.

42. Id. at 589 .

43. An Order for Marriage, in The Book of Common Prayer 435, 436 (1979 version) (Oxford U. Press)

44. Pub. L. No. $93-148, \S 2$, Nov. $7,1973,87$ Stat. 555,50 U.S.C. $\$ \S 1541-48$ (2002).

45. Pub. L. No. $93-344$, $\S 2$, July $12,1974,88$ Stat. 297 , codified at 2 U.S.C. $\$ \S 62-88$

46. See Sidak, 77 Geo. L.J. at 2130 n.221 (cited in note 13).
} (2002). 
of telling an unpopular, grasping President that a nation weary of war and sacrifice would no longer accede to extravagant claims of threats to national security-and if that meant exaggerating the constitutional limits on presidential power during times of true national peril, then so be it.

\section{The PREDictive USELESSNESS OF YOUNGSTOWN}

So what guidance could we expect to glean from Youngstown after September 11, 2001, if President Bush were temporarily to conscript private property in the name of winning the war on terrorism? Not much, most likely. A modern replay of Youngstown during the war on terrorism would likely have a different result. Consider the following not-so-hypothetical example.

When the United States began bombing Afghanistan in the fall of 2001, there was talk of using thermobaric bombs - known as fuel air explosives (FAEs) - to suck the oxygen from the mountain caves of Tora Bora, where Osama Bin Laden and AlQaeda leaders were believed to have taken refuge. In December of 2001, however, the Joint Chiefs of Staff revealed that the U.S. Air Force was not using FAEs in Afghanistan because the stock of these weapons had been exhausted during the Persian Gulf War and had not been replenished. ${ }^{47}$ The unavailability of FAEs meant that either ground troops (including American soldiers) might have to fight cave-to-cave in search of terrorists, or that other ordnance would have to be used, such as expensive cruise missiles, satellite-guided joint direct attack munitions (JDAMs), or massive BLU-82/B bombs (known as Daisy Cutters). Moreover, by late December of 2001, London's Daily Telegraph reported that, following the Afghanistan campaign, the United States would have to delay any potential attack on Iraq in the

47. In a press briefing on December 10, 2001, Rear Admiral John Stufflebeem answered the following question:

Q: You mentioned the daisy cutter. What about fuel air explosives? Have

those been used to date, and do you plan on using those to actually suck the air out of some of these caves?

Stufflebeem: I don't think they have been used to date. It's been a long time since I've looked at our inventories, but I'm not sure that we have any fuel air explosives left in the inventory from after Desert Storm.

Department of Defense News Briefing-Deputy Secretary of Defense Paul Wolfowitz and Rear Adm. Stufflebeem, Dec. 10, 2001 (available online at <http:/www.defenselink. $\mathrm{mil} /$ news/Dec2001/t12102001_t1210dsd.html >). By March 2, 2002, however, U.S. warplanes did drop two thermobaric bombs in Afghanistan for the first time. Peter Baker and Susan B. Glasser, U.S. and Afghan Forces Attack Al Qaeda Refuge; one American dies in heavy fighting, Wash. Post A1 (Mar. 3, 2002). 
war on terrorism because the supply of cruise missiles also had dwindled. ${ }^{48}$ Meanwhile, the United States was rushing to develop a more sophisticated version of the Daisy Cutter. ${ }^{49}$

With these actual facts as background, suppose that in early 2002 President Bush faced a strike not at steel plants as President Truman did in Youngstown, but at aerospace and electronics companies (such as Boeing and Lockheed Martin) that manufacture or supply critical components for FAEs, cruise missiles, JDAMs, and Daisy Cutters. Would Youngstown deny President Bush the power to seize those plants temporarily to ensure the timely production of these essential weapons in the war on terrorism?

A Supreme Court populated by hermits might promptly hold, on the authority of Youngstown, that such action was unconstitutional. But I doubt that the Court would restrain President Bush's action in this situation by finding him to be acting outside his powers as Commander-in-Chief. The same cases of government confiscation of private property during war that Justice Black said "need not concern" the Court in Youngstown might be dispositive on this more compelling set of facts. ${ }^{50}$ Moreover, after September 11, 2001, the Court might separately consider whether Youngstown is distinguishable on purely constitutional grounds. Chief Justice Rehnquist, who clerked for Justice Jackson when Youngstown was decided, made the following conjecture in his 1987 book about the Supreme Court:

I think that if the steel seizure had taken place during the Second World War, the government probably would have won the case under the constitutional grant to the president of the war power, but I also have the distinct feeling that if the American objectives and strategy in Korea had been less un-

48. The Daily Telegraph reported:

Plans for a full-scale strike on Iraq by the United States have been thrown into disarray because of a shortage of cruise missiles. America's supply of the air launched model, one of the US air force's most sophisticated and deadly weapons, has become so depleted that military chiefs are pressing Boeing, the manufacturers, to speed up their production.

Even so, the first of the new batch of missiles ordered last year is not expected for months, and it may take longer to rebuild stocks to a level that would make such an attack viable.

Strikes against Afghanistan and Sudan in 1998 and Kosovo two years ago virtually exhausted the US supply. The number of conventional [non-nuclear] airlaunched cruise missiles left within the inventory is believed to be fewer than 30 . Sean Rayment, US Missile Shortage Delays Iraq Strike, Sunday Telegraph 2 (Dec. 30, 2001).

49. Id.

50. Youngstown, 343 U.S. at 587. 
certain, the government probably would have fared better in the Supreme Court even without being able to resort to the president's war power.

The terrorist attacks of September 11th resemble the attack on Pearl Harbor far more than the frustrating prosecution of the Korean War. The attacks of 1941 and 2001 occurred on U.S. territory and directly targeted the U.S. military. They immediately placed the United States at war, without any declaration of war by Congress being necessary for the President to exercise all available constitutional powers as Commander-in-Chief. ${ }^{52}$ In contrast, the American involvement in the Korean War did not start with an attack on U.S. territory or U.S. military forces, and Congress certainly did not declare war against North Korea, China, or any other nation. As Chief Justice Rehnquist has observed, "President Truman and his top advisers deliberately refrained from asking Congress for a declaration of war[.]",33 In contrast, the steel strike of 1952 followed a long buildup of tension between labor and management, and President Truman had by that time been prosecuting the war for more than a year. Although steel is a raw input for tanks, airplanes, and bombs, it was more removed from the war effort in Korea in 1952 than is the manufacture of fuel air explosives and cruise missiles in the war in 2002 in Afghanistan and other nations that harbor terrorists.

To ignore how historical context and the personal experiences of the Justices would affect their reading of the Constitution after September 11th would be to impute to them an unnatural and unbelievable detachment from the world surrounding them. After all, the threat of anthrax letters following the September 11th attacks forced the current Court to decamp from its ornate building in the fall of 2001. The war on terrorism would not permit the Justices to be hermits even if they wished it.

\section{LIBERTY AFTER SEPTEMBER 11, 2001}

Justice Jackson said, in probably the most frequently quoted sentence of his concurrence in Youngstown, that the separation of

51. William H. Rehnquist, The Supreme Court: How It Was, How It Is 97 (William Monroe \& Co., 1987)

52. See Sidak, 41 Duke L.J. at $75-79$ (cited in note 13). For more than 150 years, Congress has declared war only when it has been constitutionally unnecessary for the President to receive a declaration of war to wage war. Id.

53. Rehnquist, The Supreme Court: How It Was, How It Is at 96 (cited in note 51). 
powers "diffuses power the better to secure liberty." 54 This statement is a positive conjecture about how American constitutional governance works. Some distinguished skeptics have questioned whether as an empirical matter the separation of powers has succeeded in protecting individual liberty relative to some counterfactual arrangement, such as Britain's parliamentary system. ${ }^{55}$ Assuming arguendo that the American separation of powers has indeed succeeded in limiting the power that government exercises over individuals, how well does Justice Jackson's vaunted dictum hold during wartime, when individual rights presumably have been most jeopardized by governmental interference?

Youngstown protected the right to private property against presidential confiscation during wartime. But the broader sweep of American history might cast that decision as more the exception than the rule. Abraham Lincoln's suspension of habeas corpus during the Civil War, ${ }^{56}$ Woodrow Wilson's secret "loyalty order"57 and his imposition of "voluntary censorship" during World War $\mathrm{I}^{58}$ and Franklin Roosevelt's internment of Japanese Americans during World War $\mathrm{II}^{59}$ all tend to portray Justice Jackson's assess-

54. 343 U.S. at 635 (Jackson, J., concurring).

55. See, e.g., Friedrich A. Hayek, 1 Law, Legislation and Liberty: Rules and Order 1 (U. of Chicago Press, 1973); Richard A. Posner, Constitutional Scholarship: What Next?, 5 Const. Comm. 17, 18 (1988).

56. Ex Parte Milligan, 71 U.S. 2 (1866); see also Ex Parte Merryman, 17 F. Cas. 144 (C.C.D. Md. 1861) (No. 9487); Clinton L. Rossiter, Constitutional Dictatorship: Crisis Government in the Modern Democracies 223-39 (Princeton U. Press, 1948).

57. By a confidential executive order issued the day after the United States declared war on Germany, Wilson directed:

The head of a department or independent office may forthwith remove any employee when he has ground for believing that the retention of such employee would be inimical to the public welfare by reason of his conduct, sympathies or utterances, or because of other reasons growing out of the war. Such removal may be made ... a matter of confidential record, subject, however, to inspection by the Civil Service Commission.

Executive Order (Apr. 7, 1917), reprinted in Edward S. Corwin, The President: Office and Powers, $1787-1984$ at 429-30 n.100 (Randall W. Bland, Theodore T. Hindson and Jack W. Peltason, eds., 5th rev. ed. New York U. Press, 1984).

58. By presidential order on April 13,1917, Wilson created the Committee on Public Information - composed of one civilian and the Secretaries of State, War, and Navy which at first requested and later directed the press to suppress certain stories concerning the war. Proclamation (Apr. 13, 1917), reprinted in 17 A Compilation of the Messages and Papers of the Presidents 8247 ["Messages and Papers"]. See also Corwin, The President: Office and Powers, 1787-1984 at 272 \& $502 \mathrm{n} .24$ (cited in note 57). Within two weeks of the attack on Pearl Harbor, Franklin Roosevelt similarly established an Office of Censorship, to report directly to the President and to be headed by the then executive news director of the Associated Press. Executive Order No. 8985 (Dec. 19, 1941), reprinted in 1941 The Public Papers and Addresses of Franklin D. Roosevelt 574 (Samuel I. Rosenman ed., Harper \& Bros.).

59. Korematsu v. United States, 323 U.S. 214 (1944). For a contemporaneous denunciation of the decision, see Eugene V. Rostow, The Japanese American Cases-A Disas- 
ment of the purpose served by the separation of power as an article of constitutional faith that falls short of being a persuasive positive theory of constitutional law. In none of these notorious instances did Congress or the Supreme Court check the President's infringement of individual liberty in the name of prosecuting a war.

Also, there is a curious inversion of priorities here. Economic liberty has been less protected from (peacetime) government regulation since at least 1937, while individual freedom has been elevated in its constitutional status. ${ }^{60}$ It is curious that Youngstown would draw a line in the sand with respect to the taking of private property, while Korematsu drew no such line with respect to individual freedom only eight years earlier. ${ }^{61}$ After September 11th it seems likely that both liberty and property will receive diminished constitutional protection in the face of national security concerns, even when they are manifested in presidential assertions of prerogative - that is, actions not expressly authorized by legislation or constitutional text.

\section{A. LIBERTY AND COMPELLING GOVERNMENTAL INTERESTS}

At the most fundamental level, September 11th has made it respectable to speak of conflicts between good and evil. ${ }^{62}$ To believe in the existence of evil is no longer to be regarded as superstitious, antiquarian, or fanatical. The attack on the United States by Islamist terrorists was an empirical fact: The world still contains "evil-doers," to use President Bush's phrase. ${ }^{63}$ It is naive and dangerous to pretend otherwise.

That insight, from experience, should cause both litigants and courts to temper their constitutional rhetoric. September 11th is the page of history to Youngstown's volume of logic. Not every governmental action presents a slippery slope taking us to a loss of civil liberty. The federal government has a compelling interest in preventing terrorists from murdering its citizens, devastating its cities, and plunging its industries and their employees

ter, 54 Yale L.J. 489 (1945).

60. See W. Coast Hotel Co. v. Parrish, 300 U.S. 379 (1937); NLRB v. Jones \& Laughlin Steel Corp., 301 U.S. 1 (1937); see also United States v. Carolene Products, 304 U.S. 144, 153 n.4 (1938).

61. Korematsu, 323 U.S. 214.

62. See, e.g., Ron Rosenbaum, Degrees of Evil: Some Thoughts on Hitler, bin Laden, and the Hierarchy of Wickedness 289 The Atlantic Monthly 63 (Feb. 2002).

63. Remarks by the President Upon Arrival, The South Lawn, 37 Weekly Comp. Pres. Doc. 1322 (Sept. 16, 2001) ("We will rid the world of the evildoers."). The biblical allusion in the President's choice of words was obvious. See, e.g., Psalm 59 ("Rescue me from evildoers and save me from those who thirst for my blood."). 
into financial chaos. September 11th reminds us why Englishspeaking peoples since 1549 have repeated Thomas Cranmer's prayer for God's deliverance "from violence, battle, and murder; and from dying suddenly and unprepared." 64

The debate over racial, ethnic, or religious profiling of Arabs or Arab Americans poses this issue of slippery slopes. Ignorant journalists sometimes speak as though racial or ethnic discrimination is unconstitutional per se. Under this misconception, any racial or ethnic profiling to detect terrorists would violate the Equal Protection Clause of the Constitution. ${ }^{65}$ The correct question to ask is whether racial or ethnic profiling of Arabs or Arab Americans to combat terrorism would survive strict scrutiny. Once the issue is correctly characterized, it would seem likely that no reasonable disagreement could exist over the compelling governmental interest at stake. One September 11th massacre is one too many. Indeed, the first bombing of the World Trade Center, in 1993, should have been one too many. The only reasonable disagreement can be over whether the means employed to combat terrorism are narrowly tailored to achieve that compelling governmental interest. ${ }^{66}$

September 11th offers a lesson for Congress and state legislatures also. Those defending statutes against constitutional challenge often resort to a form of inflation: Nearly everything the government does is a "compelling" interest. Just as it would seem that no student at Harvard or Stanford would have been admitted if he or she were not expected to get an A in most courses, so also it would seem that the mere fact that a legislature enacts a law means that the governmental objective embodied in that law must be a compelling one for purposes of judicial review. Inflation cheapens any currency, whether it is the U.S. dollar, an A at a prestigious university, or the notion of what is a compelling governmental interest. The image of the World Trade Center towers collapsing should instill some sobriety in

64. The Great Litany, in The Book of Common Prayer 148, 149 (1979 version) (Oxford U. Press). In the Elizabethan English of Cranmer's original text, the Great Litany prayed for deliverance "from battaile and murther, and from sodain death." The Litany and Sufferages, in The Book of Common Prayer (1549 version). The wording most familiar to the Framers was: "from battle and murder, and from sudden death." The Litany, in The Book of Common Prayer (1662 version).

65. U.S. Const., Amend. XIV.

66. Cf. Michael Stokes Paulsen, A RFRA Runs Through It: Religious Freedom and the U.S. Code, 56 Mont. L. Rev. 249, 263-83 (1995) (discussing the history of asserted "compelling" government interests in the religious freedom area and suggesting principles for correcting its deficiency). 
this respect. Not all "compelling" governmental interests are equally compelling. Compared with the objective of preventing or punishing terrorism, most "compelling" government interests offered up are embarrassingly flimsy and wrongly distract attention from more weighty challenges.

This recognition of the insubstantiality of what heretofore we had been willing to call "compelling" governmental interests corresponds with a number of trends commented upon in the popular press after September 11th. Foremost among them was the complete revision of Congress's legislative agenda. Before September 11th, Social Security reform was a high priority. No doubt the preamble or legislative history to such reform legislation would tell a story of how it is a compelling governmental interest to avoid the projected insolvency of the Social Security trust fund several decades from now so as to ensure that retirees receive their expected benefits. But no one could respectably argue that protecting Social Security recipients forty years hence from loss of retirement payments is more important than protecting American citizens today from loss of life due to terrorist attacks. Congress's subordination of certain issues on the legislative agenda is one proxy by which the courts can order, through a kind of legislative revealed preference, the genuine hierarchy of governmental goals for purposes of judicial review.

\section{B. RELIGION}

Perhaps, September 11th has changed how we regard government's entanglement with religion. The nation took solace in religious expressions of public grief. Christmas 2001 was muted and noticeably devoid of the usual lawsuit that a crèche scene in front of city hall was shaking America to its foundations, threatening the establishment of a state religion by fanatical Christians. ${ }^{67}$ The establishment of religion had a new understanding, from new experience, that placed matters in perspective in several respects.

First, no asserted establishment of religion occurring in the United States in 2002 could possibly compare with practices of the former Taliban regime. The subjugation of women, the forced amputations, the public executions in Kabul's soccer stadium were a far cry from a prayer at a graduation ceremony or

67. E.g., County of Allegheny v. ACLU Greater Pittsburgh Chapter, 492 U.S. 573 (1989) (menorah constitutional, crèche scene unconstitutional). 
high school football game. ${ }^{68}$ Islamist fanaticism was distinguishable in kind and in degree from government accommodations in the United States of private expressions of religious belief in the public square. The Taliban regime was a reminder to Americans to refrain from crying wolf and to view slippery-slope arguments about the government's establishment of (Judeo-Christian) religion in the United States with a skepticism born of practical experience rather than the innocent shrillness that sometime attends rationalist abstraction.

Second, a serious question was debated: Is the United States at war with terrorists and the regimes that sponsor or shelter them, or is the United States really at war with Islam itself? ${ }^{69}$ There were, of course, numerous assurances from President Bush that the latter was not the case and that the United States regarded Islam as a religion that preaches peace and toleration. But the emphasis with which this message was officially disseminated-from the President's solicitation of donations for Afghan children to his observance of Ramadan in the White Housecaused some to question whether the government's policy in this respect was propaganda intended to mollify Muslim nations whose assistance the United States wanted in its war on terrorism. It might have appeared to some that the government was doing considerably more in the fall of 2001 to accommodate Islam in the United States than, say, Roman Catholicism. In his powerful speech before Congress and Justices of the Supreme Court on September 20, 2001, President Bush said, addressing "Muslims throughout the world," that "those who commit evil in the name of Allah blaspheme the name of Allah."70 The government would seem to be deeply entangled with religion when the President uses the authority of his office to announce to the other branches of government, the nation, and world at large what constitutes blasphemy as a matter of Islamic doctrine. This presidential message was uncharted territory, and it appeared that no one would complain about a modest amount of U.S. government certification of Muslim religious doctrine if that was the price of gathering the support of Muslim countries in the war

68. See Santa Fe Indep. Sch. Dist. v. Doe, 530 U.S. 290 (2000) (holding prayer at public high school football game unconstitutional); Lee v. Weisman, 505 U.S. 577 (1992) (holding prayer at public school commencement unconstitutional).

69. For exploration of the conflict between Islam and the West, see Bemard Lewis, What Went Wrong Western Impact and Middle Eastern Response (Oxford U. Press, 2001); Bernard Lewis, The Middle East: A Brief History of the Last 2,000 Years (Scribner, 1995). 2001 .

70. Address to a Joint Session of Congress and the American People, Sept. 20, 
on terrorism, a foreign policy objective considered advantageous for the effective prosecution of the war. Still, the war of information and propaganda being waged by the United States was establishing an official view of Islam that delved far more deeply into matters of religious doctrine than did the nondenominational prayers at graduations and football games that previously had been considered weighty controversies deserving and receiving the Supreme Court's attention.

Third, Americans were confronted with the unsettling question: What if there is an irreconcilable divide between the Islamic world and the western world, the latter being largely but not exclusively Judeo-Christian in its religious foundation? Was President Bush's faux pas in the early days after September 11th, in which he used the word "crusade" to describe the intended response of the United States and its allies, actually a more accurate picture of American sentiment than the public face of toleration toward Islam that was carefully scripted to follow? ${ }^{71}$ If our enemy were not a sovereign nation, but rather a stateless army of religious fanatics, how would that enemy fit within the conventional notions of war? For example, congressional expressions of approval or disapproval of the President's prosecution of the war (as manifested, for example, in actions taken pursuant to the War Powers Resolution) would have to be couched in terms of legislation defining an enemy by its religious fervor rather than its nationality or geography. ${ }^{72}$ And, to mix constitutional doctrine, how could the United States be actively attempting to capture or kill members of Al-Qaeda or the Taliban leadership without manifesting hostility toward a group that defines itself by its extremist interpretations of Islamic teachings? Of course, such curiosities did not get in the way of the President's prosecution of the war. But that fact does not mean that the answers are easy.

\section{GOVERNORS}

The aftermath of September 11th raised a federalism issue. On November 1, 2001, Governor Gray Davis, acting on a nonpublic FBI warning, deployed the California Highway Patrol and

71. Remarks by the President Upon Arrival, The South Lawn, 37 Weekly Comp. Pres. Doc. 1323 (Sept. 16, 2001) ("This crusade, this war on terrorism is going to take a while.").

72. Cf. J. Gregory Sidak, True God of the Next Justice, 18 Const. Comm. 9 (2001) (arguing that it is both intractable and improper for senators to question a judicial nominee about either the tenets of his religious sect or the intensity of his religious devotion). 
the National Guard to defend against the threat of an imminent terrorist attack on the Golden Gate Bridge and other major bridges in the state. ${ }^{73}$ Some unnamed federal officials criticized him for disclosing the FBI's warning and, they asserted, overreacting to it. ${ }^{74}$ The implication of the criticism was that the governor was stepping on the Commander-in-Chief's turf. ${ }^{75}$ If the motivation for that criticism was more than partisan political pique (Governor Davis would be a plausible presidential candidate challenging President Bush in 2004), then perhaps it sprang from the same concerns that motivated the Supreme Court a decade earlier to reprimand one governor for trying to direct U.S. foreign policy by placing limits on the use of his state's national guard. $^{76}$

But any criticism of Governor Davis on this occasion was unjustified, because the Constitution empowers him to wage war. The circumstances, of course, are limited: "No State shall, without the Consent of Congress,... engage in War, unless actually invaded, or in such imminent Danger as will not admit of delay." by the President's power to command "the Militia of the several States, when called into the actual Service of the United States." $" 78$

In light of the carnage of September 11th, an FBI warning of an imminent terrorist attack surely satisfies the requirement of "imminent Danger." After all, Attorney General Ashcroft, his ashen face suggesting that he knew more than he could say, had made multiple televised warnings of credible but unspecified threats of further, imminent terrorist attacks. There can be no quibbling that, if a state may "engage in War" when the imminent danger can be discerned with sufficient clarity to respond, then the state also may, when confronted by such warnings from the federal government, engage in measures short of engaging in war that afford that state's citizens the best available defense against war, invasion, or actual danger.

73. Susan Sward, Mark Martin and Henry K. Lee, Davis Reveals Warning of Attacks on Bridges; Governor Blasted for "Overreacting"-Security Boost on 4 State Spans, S.F. Chron. A1 (Nov. 2, 2001).

74. Id.

75. Id.

76. Perpich v. Dep't. of Def., 496 U.S. 334 (1990).

77. U.S. Const., Art. I, $\$ 10$, cl. 3 (emphasis added).

78. Id., Art. II, $\$ 2$, cl. 1 . 
Finally, who decides whether the imminent danger "will not admit of delay"? This question must rest with the state-and there, with the governor as the state's analog to a commanderin-chief. Any federal role in the decision would make the clause unnecessary. in the first place. If a federal court or Congress or the President could review the governor's decision, then this constitutional grant of power to the states would be one that could never be exercised, and thus the clause would be pointless verbiage. On November 2, 2001, President Bush rendered a political opinion of sorts that is consistent with such a constitutional interpretation. He backed up Governor Davis on his warning to Californians: "As a former governor, I didn't particularly care when the federal government tried to tell me how to do my business ... And I think any governor should be able to conduct their business any way they see fit." ${ }^{\text {"79 }}$ Uncertainty begets prerogative and deference. As Governor Davis said, there is "no playbook for these times." 80

\section{CONCLUSION}

The ancient Egyptians designed Abu Simbal so that, for only a few minutes twice each year, the first rays of sunrise illuminate the temple's inner sanctum. September 11, 2001, was like that infrequent shaft of sunlight. It will change how we read the Constitution, and it will diminish the value of the elegant abstraction of a famous court decision like Youngstown. September 11 th was an intense, common experience that informed us about the balance between individual liberty and collective security. That experience reminds us that the text of the Constitution is replete with references to war, because the same Framers who devised the separation of powers and later wrote the Bill of Rights also saw the need to be vigilant in a dangerous world. It is an exaggeration to say that everything is different now. The words of the Constitution have not changed since September 11th. It has always been the case that the first duty that Article II, section 2 imposes on the President is to be Commander-inChief. What has changed, through experience, is our collective understanding of why the government's highest obligation under the Constitution is to defend its citizens.

79. Carla Marinucci and Marc Sandalow, Bush Backs Davis on Release of Bridge Alert, S.F. Chron. A8 (Nov. 3, 2001).

80. Id. 